平成元年レーザー学会学術講演会第 9 回年次大会

26a III 9 (招待講演)

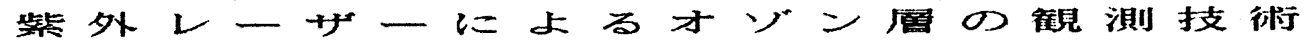

国立公害研究所

中根英昭

1.はじめに

フロンによるオゾン層破壇の可能性は1970年代から指摘されてきたか、成層圈オゾ ン搌度の減少傾向が観測事実として存すると認められたのは、南極では1984年から 1985年にかけてのオソンホールの発見以降であり、地球規模では1988年3月にオソント レンドバネルの結果が発表されてからである。他方、対流圈オソンは年に約 $1 \%$ 增加 している。從つて、フロンによるオソンン層破壊の速度を正確に知るためには、オソン 浱度の鉛直分布、とりわけオソン破壊が最も顕著に進むと予想される高度 $40 \mathrm{~km}$ 付近の オゾン浱度鉛直分布を精度良く観測する必要がある。このような時代の要請とエキシ マーレーザーの発達によって、レーザーレーター方式のオゾン観測が注目されるよう になった。本講演では各国のオゾン観測用レーザーレーターおよび1988年3月に国立公 害研究所に設置されたオソンンレーザーレーターの特徵を紹介することを通して、設計 の要点やノウハウを紹介する。

\title{
2. オソンンーザーレーダーの原理
}

レーザーレーター（ライター）によるオソンの測定は、差分吸収法またはDIAL (Differential Absorption Lidar) 法による。この方法ではオソンンよって吸収され る波長入、と吸収されない波長入っでレーザーレーダー観測を行い、2 波長の信号の減 衰を比較することによりオソン搌度を距離（高度）分解能をもって観測する。

D I A L 法によるオゾン浱度 N（R）は、次式で表わされる。

$N(R)=1 / 2\left(\sigma_{1}-\sigma_{2}\right) \cdot d\left[\ln \left\{P_{2}(R) / P_{1}(R)\right\}\right] / d R$

$$
+1 / 2\left(\sigma_{1}-\sigma_{2}\right) \cdot(B+T)
$$

$\mathrm{R}$ はレーザーからの距離、のはオソンの吸収断面積、 $\mathrm{P}(\mathrm{R})$ は信号強度である。添 字1、2は $\lambda_{1} 、 \lambda$ 2に対応する。実際のデー夕処理においては微分ではなく差分を用い る。 $\mathrm{B}$ は後方散乱係数の波長依存性が空気とエアロソルで異なることによる補正項、 Tは空気とエアロソルによるレーザー光の減衰（消散）による補正項である。エアロ ゾルの存在しない場合には $\mathrm{B}=0$ であり、 $\mathrm{I} の$ 兒積りも容易になる。エアロソルの存

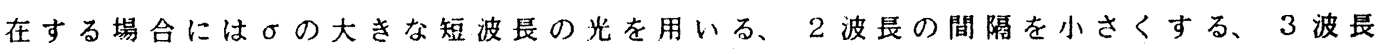
以上を用いる等の工夫が必要である。 
平成元年レーザー学会学術講演会第 9 间年次大会

3.レーザー波長の選択

オゾンの吸収スペクトルを図1に示す。吸収断 面積の大きなより短波長の光を用いると式（1） の第 2 項の影響の少ない観測ができる。また $320 \mathrm{n}$ 罟ら短波長では地上に到達する太陽光が煘少し、 $290 \mathrm{~nm}$ より短波長では事実上なくなる(ソーラーフ ラインド効果) のでバックグラウンドの少ない測 定が可能である。しかしこのことは同時に、地上

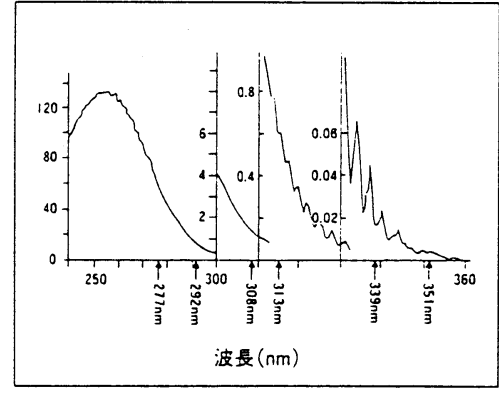

図1オゾンの吸収スペクトル

から上向きにレーザーを発射した場合に、その光

がオゾン層を突き抜ける前に減衰してしまうことを意味する。高度 $20 \mathrm{~km}$ 以下では 300

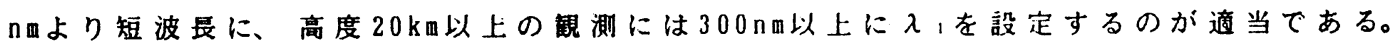
レーザーに関しては、出力、寿命、波長の自由度、操作の容易さが重要である。

高度 $40 \mathrm{~km}$ 付近のオゾン観測にはXeCIレーザー(308nm) が不可欠である。これに組み 合わせる波長 $\left(\lambda_{2}\right)$ には種々の可能性がある。XeClレーザーのSRS ( Stimulated

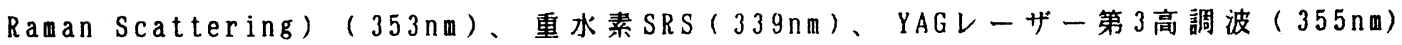
XeFレーザー( $351 \mathrm{~nm}, 353 \mathrm{~nm})$ が用いられている。YAGレーザー、XeFレーザーを用いる のは、大気密度・気温の測定を同時に行う場合である。

对流圈から下部成層圈のオゾン観測には、色素レーザーの第 2 高調波、 KrFレーザー

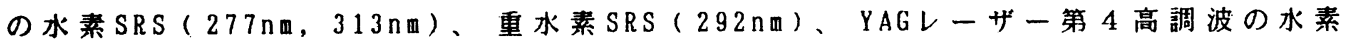
SRS $(299 \mathrm{~nm}) 、$ 重水素SRS $(289 \mathrm{~nm})$ が用いられている。

表 1 に最近各国に設置された对流圈オゾン毁測用レーザーレーダーの使用波長をま とめた。

また、表 2 には高度 $40 \mathrm{~km}$ 付近のオゾン観測が可能な各国のオソンレーザーレータ 一の波長を示した。

表 1 対流圈オソンンレーザーレーダーの使用波長

\begin{tabular}{|c|c|c|c|c|c|}
\hline 国 & \multicolumn{2}{|c|}{ 米国 } & フランス & \multicolumn{2}{|c|}{ 日本 } \\
\hline 研究機関 & $\mathrm{JPL}$ & NOAA & CNRS & 九州大 & 国公研 \\
\hline レーザー & YAG 4 th & 2 dye & YAG $4 \mathrm{th}$ & $\mathrm{KrF}$ & $\mathrm{KrF}$ \\
\hline 波最 & $289(\mathrm{D} 2)$ & variable & 289 (D2) & $277(\mathrm{H} 2)$ & $277(\mathrm{H} 2)$ \\
\hline$(n \boxplus)$ & 294 (HD) & variable & $299(\mathrm{H} 2)$ & $292(\mathrm{D} 2)$ & $292($ D 2$)$ \\
\hline & & & & $313(\mathrm{H} 2)$ & $313(\mathrm{H} 2)$ \\
\hline
\end{tabular}


平成元年レーザー学会学術講演会第 9 回年次大会

表 2 上部成層圈用オゾンレーザーレーダーの波長

\begin{tabular}{|c|c|c|c|c|c|c|c|c|}
\hline \multirow{2}{*}{\multicolumn{2}{|c|}{$\begin{array}{l}\text { 国 } \\
\text { 研 究機 関 }\end{array}$}} & \multicolumn{2}{|c|}{ 米国 } & \multicolumn{2}{|c|}{ フランス } & 西独 & \multicolumn{2}{|c|}{ 日本 } \\
\hline & & JPL & NASA & $\mathrm{CN}$ & R S & obs.Hohen. & 国公研 & 気象研 \\
\hline 波長 & $\lambda_{1}$, & & & & 308 & $\mathrm{XeCl}$ ) 共通 & & \\
\hline at ) & $\lambda=$ & 353 & 355 & 35 & & 353 & $339, \quad 351$ & 355 \\
\hline & & (H2) & (YAG & $3 \mathrm{rd})$ & & (II2) & $(\mathrm{D} 2)(\mathrm{XeF})$ & $(Y A G \quad 3 r d)$ \\
\hline
\end{tabular}

\section{4. 国立公害研のオソンンレーザーレーダー}

国立公害研究所（国公研）で は本年 3 月に対流圈・成層圈才 ゾン観測用多波長レーザーレー ターを設置した。これは、国公 研の基本設計に基ついて米国 $\mathrm{S}$ $\mathrm{T} I$ 社が製作したものである。 図 2 に装置の概要を、表 3 に仕 棣を示す。

本装置は低高度 $(1.5 \mathrm{~km}$ から $15 \mathrm{~km})$ 及び高高度 $(15 \mathrm{~km}$ か 550 $\mathrm{km}$ ）の高度領域に最適化したサ ブシステムを持っている。低高 度システームは KrFレーザーとロ径

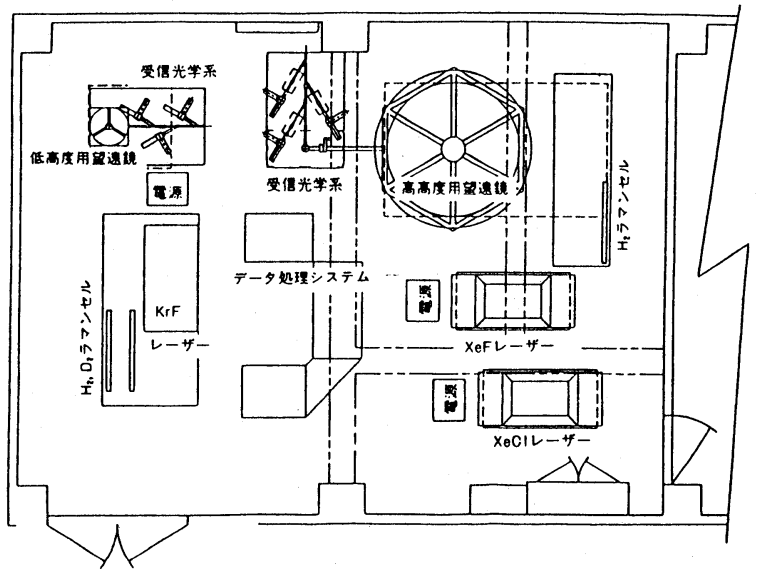

図 2 国公研オソンンレーザーレーターの榑成 $56 \mathrm{~cm}$ の望遠鏡を持ち、高高度シ ステムは狭帯域のXeClレーザー、XeFレーザーとロ径 $2 \mathrm{~m}$ 望遠鏡を持っている。

ラマンシフターの出ロはレンズではなく空にして、その後に放物面鏡を置いた。こ れにより色収差を避けるとともに、3 倍ビームエキスパンダーを構成した。高高度 ステムでは、近距離からの不用な强い信号を遮断するためにチョッバーを用いている。 受信光はタイクロイックフィルターと干涉フィルターで分光している。レーザーレー ター信号の大きなダイナミックレンジに対応するため、各波長每に $92 \%$ 光を受信する 主系統と、 $2 \%$ か 8 \%の光を受信する副系禚を設けている。

図3に高高度システムの受信信号の一例を示す。主系統、副系統の信号が異なった タイミングで遮断されている。

図4 は本レーザーレーターによって観測したオゾンと気温の鉛直分右を気球観測の 結果と比較したものである。気温の鉛直分布は、オソンの吸収を受けない351nmのXeF レーザー光を用いて観測した大気密度の鉛直分有から求めた。 $15 \mathrm{~km}$ か $525 \mathrm{~km}$ の高度で は、レーザーレーターと気球のデータの一致は非常に良い。 $30 \mathrm{~km}$ 付近ではオソン気球 観測の精度は低いことが知られている。 
表 3 国公研オソンンレーザー

\section{$レ ー タ-の$ 仕様}

低高度システム送信柔

$\mathrm{KrF}$ エヘキシマレーザ(ラムダフィジックス EMG201MSC)*

ラマンシフター(ラムダフィジックス RS75) $\times 2$

277.1nm $\mathrm{H}_{2}$ ストークス次

$313.2 \mathrm{~nm} \mathrm{H} \quad \mathrm{H}_{2}$ ストークス2次

$291.9 \mathrm{~nm} \mathrm{D}_{2}$ ストークス2次

出力 $* 27 \mathrm{~W}$ 繰り返し数 $80 \mathrm{~Hz}$

3倍ピームエキスパンダー

高高度システム送信采

$\mathrm{XeClエキシマーレーザ(ラムダフィジックス} \mathrm{EMG160TMSC)**}$

ラマンシフター(ラムダフィジックスRS75)

$308.2 \mathrm{~nm}$ 基本波

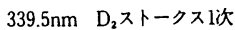

$\mathrm{XeF}$ エキシマーレーザ(ラムダフィジックス EMG160TMSC) *** $351.1 \mathrm{~nm}$ 基本波

出力 $* * 36 \mathrm{~W}, * * * 18 \mathrm{~W}$ 繰り返し数 $250 \mathrm{~Hz}$

スペクトル幅 $* * 0.003 \mathrm{~nm}, * * * 0.01 \mathrm{~nm}$

(インジェクションロック)

3倍ピームエキスパンダー

低高度システム受信系

受信望遗镜口径 : $0.56 \mathrm{~m}$, 視野角 (Typical) : 0.9mrad, 千涉フィルター バンド幅： $2 \mathrm{~nm}$, 光电子增倍管：(EMI9813) ×6,ゲインスイッチ付き 高高度システム受信系

受信望遠鏡口径： $2 \mathrm{~m}$ ，梘铮角 (Typical) : 0.4mrad, 千涉フィルターバ

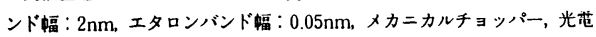
子增倍管：(EMI9813) ×6,ゲインスイッチ付き

データ収集システム

フォトンカウンター

入カチャンネル数 12 (DSP2090+4101) ×12

カウントレート $100 \mathrm{MHz}$ ，ゲート時間 $1 \mu \mathrm{s}$

セグメント数 2048

高速皘算繰り返し数 $250 \mathrm{~Hz}$ 以上，精度 $24 \mathrm{bit}$

トランジェントレコーダー

入カチャンネル数 6 (DSP2030+4100) ×6

サンプリングレート $20 \mathrm{MHz}$ ，セグメント数 8192 高速稙算綵り返し数 $250 \mathrm{~Hz}$ 以上,韧度 $24 \mathrm{bit}$

ミニコンピューター (Digital Equipment PDP11/53) 9トラック碰武テープレコーダー

このレーザーレーターは地上 $1.5 \mathrm{~km}$ 的 $50 \mathrm{~km}$ までのオソンン浱度、30k听 $580 \mathrm{~km}$ まで の気温を時間的に連続して観測できる。こ の特徵を生かして、今後、オン゙ン濃度の変 動の観測とその機構の解明、それを踏まえ た長期的なトレンドの莬出、人工衙星デ一 夕の較正等に役立てることかできるものと 期待している。

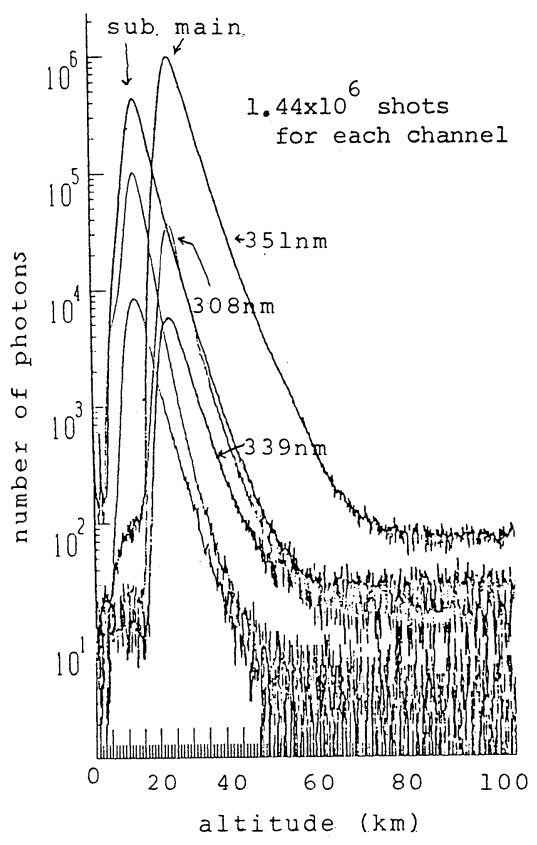

図3受信信号の例
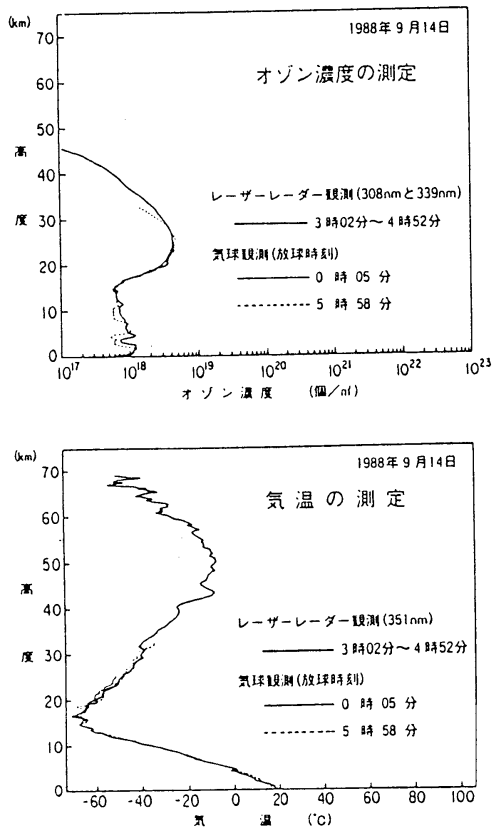

网4 気球钼測との比較 